\title{
Pemodelan Sebaran Sedimen Dasar di Perairan Pelabuhan Branta Pamekasan
}

\author{
Salman Asatidz ${ }^{1 *}$, Alfi Satriadi ${ }^{1}$, Aris Ismanto ${ }^{1}$, Heryoso Setiyono $^{1}$, Purwanto $^{1}$ \\ ${ }^{1}$ Departemen Oseanografi Fakultas Perikanan dan Ilmu Kelautan, Universitas Diponegoro. \\ Jl. Prof. H. Sudarto, SH, Tembalang Semarang, 50275 Telp/fax (024) 7474698 \\ Email: *salman.asatidz98@gmail.com
}

\begin{abstract}
Abstrak
Pelabuhan Branta, Pamekasan merupakan salah satu pintu gerbang ekonomi di Pulau Madura, sebagai tempat penghubung perpindahan barang kebutuhan pokok dari Probolinggo maupun sebaliknya. Pelabuhan ini juga digunakan sebagai sarana penunjang kegiatan perikanan tangkap di perairan selatan Kabupaten Pamekasan. Faktor keselamatan kapal dalam melakukan kegiatan di pelabuhan terhadap pendangkalan dalam area pelabuhan yang diakibatkan oleh sedimentasi perlu diperhatikan. Tujuan dari penelitian ini untuk mengetahui sebaran sedimen dasar dan perubahan dasar perairan berdasarkan hasil model. Pemodelan untuk mengetahui perubahan dasar perairan dilakukan menggunakan perangkat lunak MIKE21 modul Sand Transport dengan memasukkan data-data hasil survei lapangan seperti batimetri, pasang surut, arus, gelombang, debit sungai dan karakteristik sedimen dasar. Pemodelan dilakukan selama 31 hari (Oktober 2019). Analisa ukuran butir didapatkan bahwa sedimen dasar di Perairan Pelabuhan Branta berupa pasir, lanau pasiran dan lanau. Hasil pemodelan menunjukkan terjadi sedimentasi pada perairanh dekat pantai sebesar $0,0008 \mathrm{~m}-0,02 \mathrm{~m}$, dan terjadi erosi pada daerah laut sebesar $0,0023 \mathrm{~m}$.
\end{abstract}

Kata kunci : Sedimen dasar, pemodelan, Perairan Pelabuhan Branta

\section{Abstract \\ Modeling of Bed Sediment Distibution In the Port of Branta, Pamekasan Territorial Water}

The port of Branta, Pamekasan is one of the economic gateways on Madura Island, as a place to connect the movement of basic necessities from Probolinggo or vice versa. This port is also used as a means of supporting fishing technology activities in the southern waters of Pamekasan Regency. The safety of ship activities in the port against silting in the port area caused by sedimentation needs to be considered. The purpose of this study is to identify the bed sediment and bed level change based on the result of the model. Modelling to determine bed level change was using the MIKE21 Software Sand Transport module with parameters frol field survey such as bathymetry, tides, current, wave, river flow and bed sediment characteristics. Modelling time is set for 31 dyas (October 2019). Analysis of the bed sedimentary grain size found that bed sediment in the waters of the port of branta are sand, sandy silt and silt. Modeling result show that there is sedimentation in the nearshore area of 0.004- $0.02 \mathrm{~m}$, and erosion of the sea area of $0.0023 \mathrm{~m}$.

Keywords : Sediment, Modelling, Port of Branta territorial water

\section{PENDAHULUAN}

Pelabuhan Branta merupakan pelabuhan regional yang berada di wilayah administrasi Kabupaten Pamekasan, Madura, dikelola oleh Unit Penyelenggara Pelabuhan (UPP) Kelas III Branta. Pelabuhan Branta saat ini digunakan untuk angkutan barang dan belum melayani penumpang umum. Pengembangan fasilitas pokok pelabuhan yang dilakukan pada tahun 2013-2014 membuat Pemerintah Provinsi Jawa Timur mengupayakan untuk membuka angkutan penumpang rute Probolinggo-BrantaBanyuwangi. Pelabuhan ini dimanfaatkan oleh kapal nelayan sebagai pelabuhan sandar dalam kegiatan bongkar muat hasil tangkapan ikan dengan pengawasan dari pegawai UPP Branta (Abdurrahman dan Latief, 2017). 
Menurut Witantono dan Khomsin (2015), pemeliharaan perairan pelabuhan perlu dilakukan untuk menjamin keamanan dan keselamatan kapal dalam melakukan kegiatan bongkar muat di pelabuhan. Pemeliharaan tersebut diantaranya yaitu pemantauan proses sedimentasi yang dapat menyebabkan pendangkalan pada alur pelayaran. Pendangkalan ini dapat menyebabkan kandasnya kapal ataupun kecelakaan yang mengakibatkan terhambatnya mobilitas kapal dalam melakukan kegiatan di pelabuhan. Pemeliharaan dasar perairan pada perairan pelabuhan dibutuhkan untuk menunjang pengelolaan maupun rencana pengembangan pelabuhan (Triatmodjo, 2010).

Proses sedimentasi/erosi di Perairan Pelabuhan Branta tidak terlepas dari adanya bangunan pantai seperti dermaga pelabuhan, breakwater dan jetty di daerah pelabuhan. Bangunan pantai yang menjorok ke laut tersebut dapat mengganggu keseimbangan transportasi sedimen yang terjadi pada perairan di sekitar bangunan pantai. Hal ini menyebabkan terjadinya sedimentasi maupun erosi pada perairan di sekitarnya (Diposaptono, 2011). Menurut Karsono (2019), sedimentasi dan erosi yang terjadi pada suatu perairan merupakan dampak yang ditimbulkan dari proses transport sedimen yang berlangsung secara terus-menerus pada perairan tersebut. Proses transport sedimen terjadi dikarenakan faktor hidrooseanografi seperti arus, pasang surut dan gelombang, juga dapat diakibatkan oleh adanya sirkulasi arus dari pasang surut (Satriadi, 2013).

Ismanto, et al (2017) menyebutkan bahwa pola transport sedimen yang terjadi pada perairan dapat dipengaruhi oleh pola pasang surut. Pasang surut pada perairan dapat membangkitkan arus, arus ini dinamakan dengan arus pasang surut. Arus ini mengakibatkan terjadinya sirkulasi massa air yang dapat membawa material sedimen pada dasar perairan. Pergerakan sedimen tersebut berkaitan dengan kecepatan arus dan ukuran butir sedimen. Kecepatan arus yang dibutuhkan untuk mengangkut partikel sedimen berbanding lurus dengan ukuran butir sedimen, semakin besar ukuran butir sedimen maka semakin besar pula kecepatan arus yang dibutuhkan untuk dapat mengangkut material sedimen (Simatupang, 2016).

Perpindahan sedimen tidak hanya dipengaruhi oleh arus, faktor oseanografi yang juga berpengaruh adalah gelombang. Gelombang yang menuju pantai akan pecah pada perairan dangkal karena perubahan kedalaman. Gelombang pecah ini akan mengaduk sedimen pantai sehingga terjadi perpindahan sedimen dasar. Perpindahan sedimen yang berlangsung terus menerus akan menyebabkan terjadinya sedimentasi atau erosi pada suatu perairan (Astuti et al., 2016).

Kajian mengenai perubahan dasar perairan sudah banyak dilakukan. Informasi mengenai perubahan dasar perairan akibat pembangunan di suatu wilayah penting dilakukan. Hal ini untuk mengetahui dampak dari pembangunan terhadap perubahan kontur dasar perairan. Informasi ini dapat digunakan menjadi bahan informasi bagi pengelola pelabuhan dalam mengambil keputusan masalah manajemen dan pengelolaan wilayah pantai. Perubahan dasar perairan (bed level change) dapat ditinjau menggunakan line series, tetapi akan lebih baik jika dapat mengetahui perubahan secara area (Fahmi, 2015).

Berdasarkan uraian diatas, maka diperlukan kajian dan analisa pola transport sedimen dasar melalui pemodelan, serta faktor-faktor yang mempengaruhi proses transport sedimen diantaranya yaitu arus dan gelombang. Pemodelan transport sedimen dasar ini dilakukan untuk mengetahui perubahan dasar perairan (bed level change) secara area yang terjadi di Perairan Pelabuhan Branta, Pamekasan.

\section{MATERI DAN METODE \\ Materi Penelitian}

Materi yang digunakan dalam penelitian ini meliputi data primer yaitu data arus, data gelombang, data pasang surut, data debit sungai, dan data sedimen dasar yang diperoleh secara langsung dengan survei lapangan. Data sekunder penelitian meliputi data angin dari ERA5 European Centre for Medium-Range Weather Forecasts (ECMWF) dan Peta Rupa Bumi Indonesia Skala 1:25000 tahun 2019 dari Badan Informasi Geospasial. 


\section{Metode Penelitian}

Metode penelitian yang digunakan yaitu metode kuantitatif yang merupakan suatu cara untuk memperoleh data berupa angka-angka dan analisis data dengan pendekatan statistik guna tujuan tertentu secara ilmiah. Metode kuantitatif dalam penelitian ini akan diperoleh data arus dan gelombang dengan menggunakan $\mathrm{ADCP}$, data kedalaman diperoleh dari pemeruman dengan menggunakan singlebeam echosounder, data pengukuran pasang surut dengan logger pasut, data debit sungai dengan menggunakan current meter serta data sedimen dasar dengan grab sampler. Data penunjang dalam penelitian ini diperoleh dengan melakukan pengunduhan data melalui website resmi, diantaranya yaitu www.tanahairindonesia.com untuk perolehan data Peta Rupa Bumi Indonesia, kemudian data angin diperoleh dari www.cds.climate.copernicus.eu .

Pengambilan data primer pada penelitian ini menggunakan metode purposive sampling, dengan pengambilan sampel berdasarkan pertimbangan tertentu. Pengambilan data sedimen dasar dilakukan sebanyak 19 stasiun yang ditampilkan pada gambar 1 . Pertimbangan stasiun 1 mewakili sedimen yang berasal dari sungai; stasiun 2 mewakili muara sungai; stasiun 3,5 mewakili kolam pelabuhan, stasiun 4, 6, 7 mewakili bagian pantai; sedimen 8, 9, 10,11, 12 mewakili bagian perairan dangkal, stasiun 13, 14, $15,16,17,18$, dan stasiun 19 mewakili bagian lepas pantai.

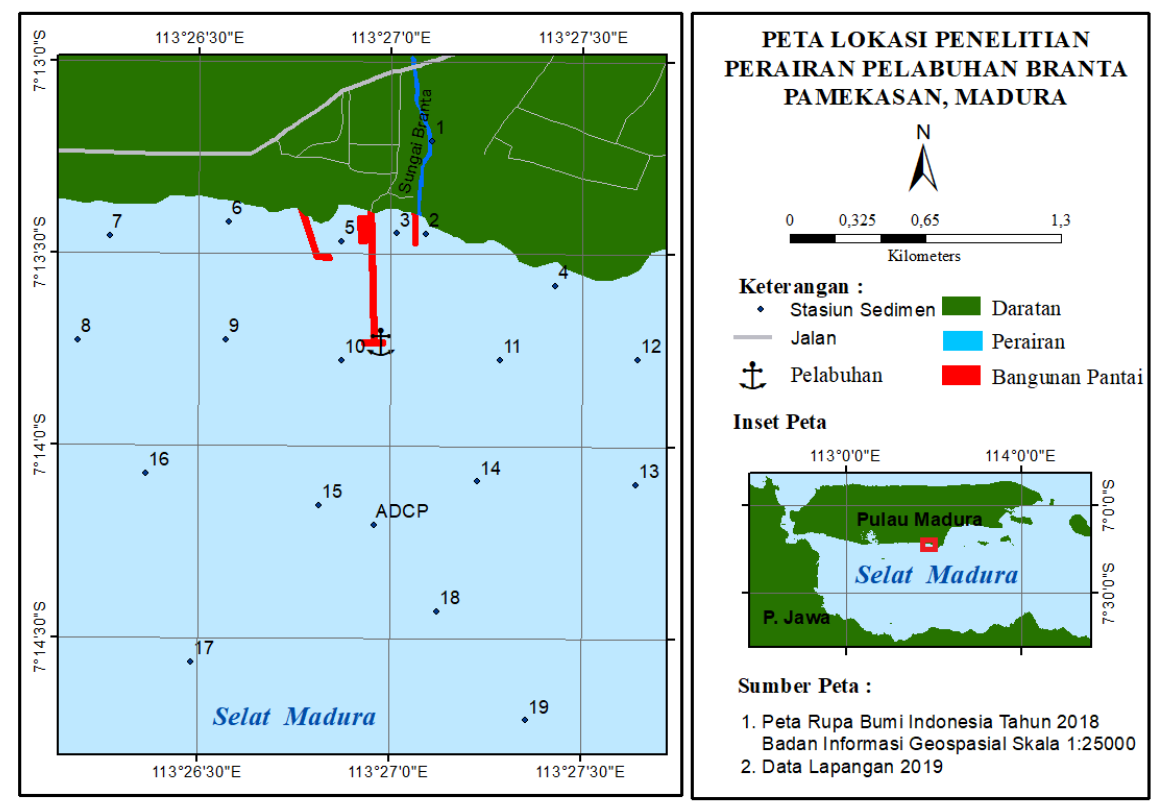

Gambar 1. Peta Lokasi Penelitian

Pengolahan data pasang surut dengan menggunakan metode admiralty, sehingga didapatkan nilai komponen-komponen pasang surut yaitu $\mathrm{S}_{0}, \mathrm{M}_{2}, \mathrm{~S}_{2}, \mathrm{~K}_{2}, \mathrm{~N}_{2}, \mathrm{~K}_{1}, \mathrm{P}_{1}, \mathrm{O}_{1}$, dan $\mathrm{MS}_{4}$. Komponen tersebut digunakan untuk menghitung bilangan Formzahl sehingga diketahui tipe pasang surut, juga untuk mengetahui nilai kedudukan muka air yang selanjutnya digunakan sebagai koreksi nilai batimetri lapangan. Data batimetri yang telah terkoreksi dengan pasang surut kemudian diolah dengan menggunakan ArcGIS 10.3 untuk mendapatkan peta kontur kedalaman. Sampel sedimen dasar dianalisis ukuran butirnya dengan menggunakan metode Buchanan (1984) yaitu melakukan pengayakan dan pemipetan sampel sedimen. Hasil analisa diplotkan pada sieve graph dan penamaan jenis sedimen menggunakan segitiga shepard.

Simulasi pemodelan arus dilakukan menggunakan software MIKE21 Flow Model FM dengan menggunakan parameter yaitu pasang surut, angin dan batimetri. Simulasi pemodelan gelombang menggunakan software MIKE21 Spectral Wave dengan menggunakan data area series dari hasil pemodelan arus, dan data gelombang hasil peramalan. Hasil pemodelan arus dan gelombang kemudian diolah dengan perangkat lunak ArcGIS 10.3 untuk pembuatan layout peta. Simulasi perubahan dasar 
perairan menggunakan modul Sand Transport, dengan parameter hasil pemodelan arus dan gelombang, debit sungai, data ukuran butir sedimen.

\section{Validasi}

Validasi model pada penelitian ini menggunakan validasi RMS yang dapat digunakan untuk menunjukkan kecocoka dua jenis data yaitu antara data model dengan data lapangan (Ismanto et al., 2019). RMS adalah salah satu metode verifikasi untuk mengevaluasi teknik peramalan yang digunakan guna mengukur tingkat akurasi hasil prakiraan suatu model yang sudah dibuat (Makridakis dan Wheelwright, 1999). Persamaan menghitung RMS adalah sebagai berikut:

Keterangan:

$$
R M S E=\sqrt{\frac{\sum_{i=1}^{n}\left(x_{m}-x_{e}\right)^{2}}{n}}
$$

RMS : Nilai Root Mean Square Error

$x_{m} \quad$ : Data Awal (Data Sebenarnya)

$x_{e} \quad$ : Data Akhir (Data Hasil Estimasi)

$\mathrm{N} \quad$ : Jumlah Data

\section{HASIL DAN PEMBAHASAN}

Data pasang surut diolah menggunakan metode Admiralty untuk mendapatkan nilai amplitude (A) dan beda fase $\left(\mathrm{g}^{\circ}\right)$ dari komponen pasang surut yang disajikan pada Tabel 1 .

Tabel 1. Komponen pasang surut

\begin{tabular}{ccccccccccc}
\hline & S0 & M2 & S2 & N2 & K1 & O1 & M4 & MS4 & K2 & P1 \\
\hline $\mathbf{c m}$ & 223 & 12 & 9 & 22 & 13 & 9 & 0,2 & 0,1 & 2 & 4 \\
$\mathbf{g}^{\mathbf{0}}$ & & 216 & 322 & 184 & 309 & 166 & 254 & 185 & 322 & 309 \\
\hline
\end{tabular}

Komponen pasang surut tersebut dapat digunakan untuk mengetahui tipe pasang surut dengan melakukan perhitungan nilai formzahl. Nilai formzahl yang didapatkan yaitu sebesar 1,01, nilai ini menunjukkan bahwa tipe pasang surut pada Perairan Branta, Pamekasan yaitu tipe pasang surut campuran condong ganda. Tipe pasang surut ini ditandai dengan terjadinya dua kali pasang dalam sehari dengan interval yang berbeda seperti ditunjukkan pada Gambar 2.

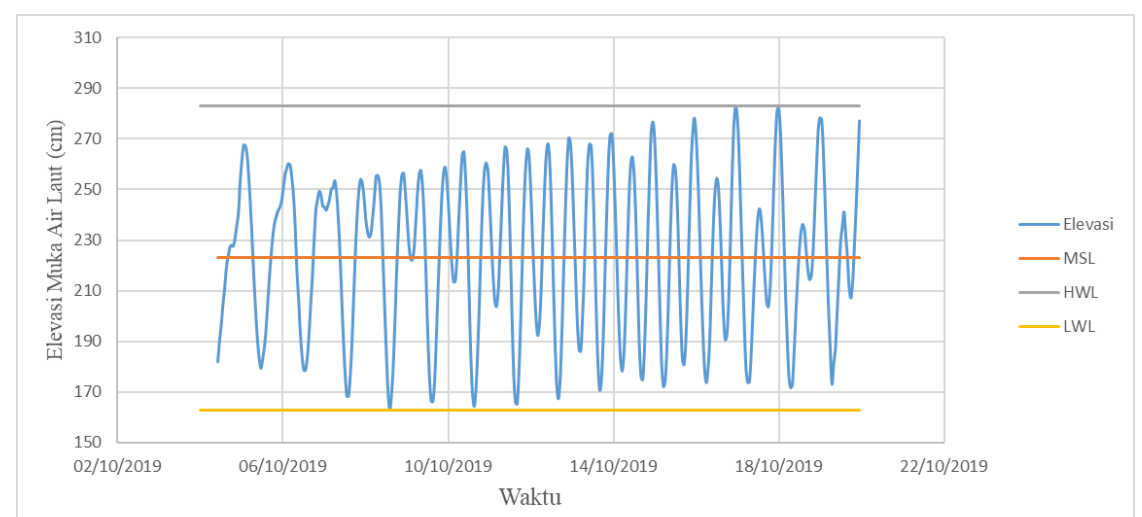

Gambar 2. Grafik pasang surut di Perairan Pelabuhan Branta, Pamekasan pada 4 - 19 Oktober 2019 
Data Arus pada penelitian ini didapatkan dari pengukuran secara langsung pada 4-7 Oktober 2019 dengan menggunakan ADCP Argonaut SonTek XR. Dari hasil current rose yang disajikan pada gambar 3 didapatkan bahwa arah arus yang terjadi di perairan pelabuhan branta dominan bergerak dari arah barat laut dan dari arah tenggara dengan kecepatan arus dominan yaitu $0,10-0,12 \mathrm{~m} / \mathrm{s}$.

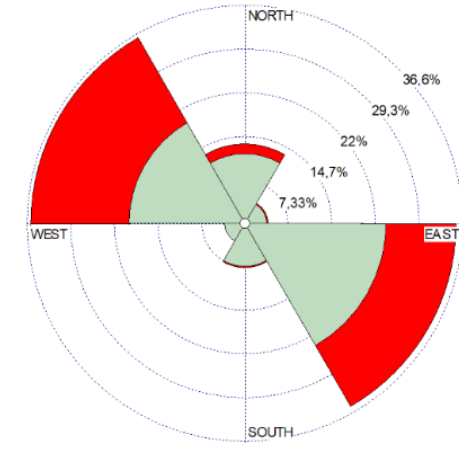

(a)

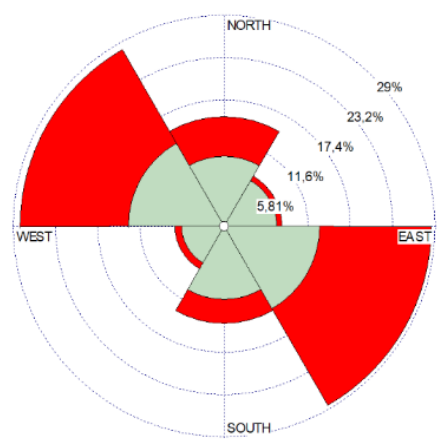

(b)

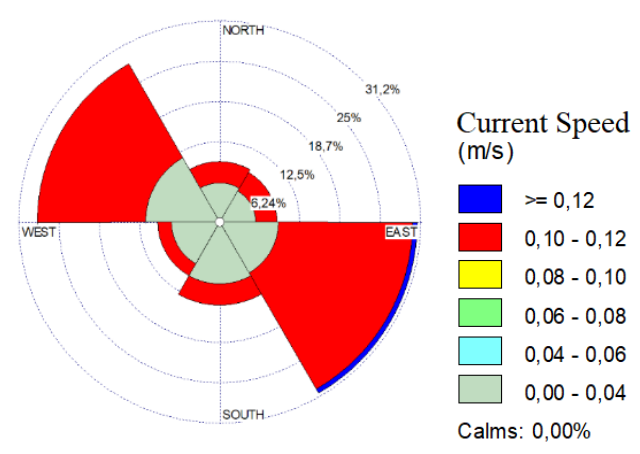

(c)

Gambar 3. Current Rose Kecepatan dan Arah Arus pada kedalaman : (a) Dasar; (b) Tengah; (c) Permukaan

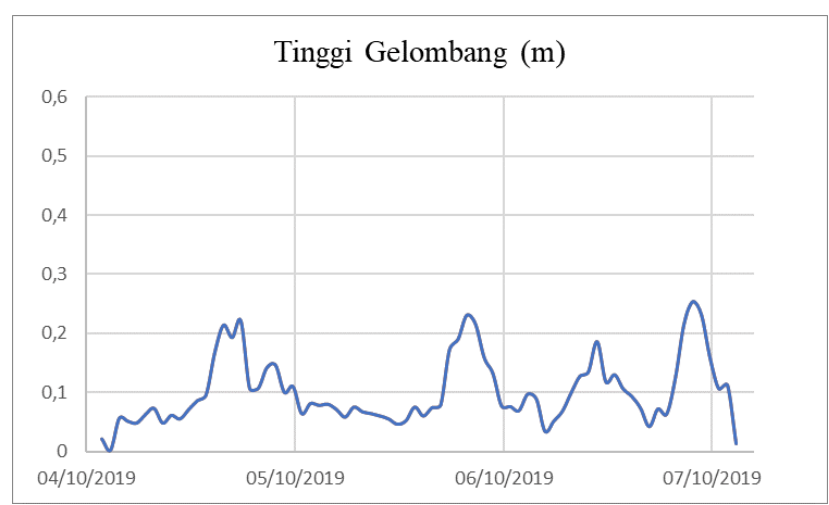

Gambar 4. Tinggi Gelombang Lapangan

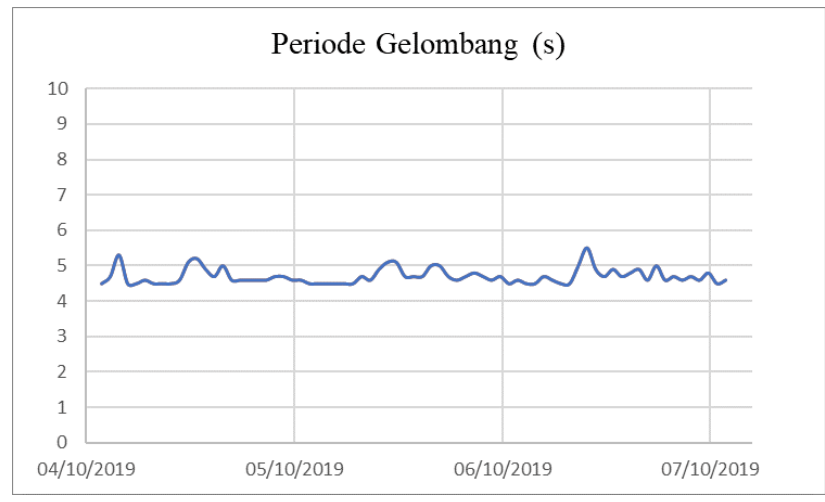

Gambar 5. Periode Gelombang Lapangan

Berdasarkan hasil pengukuran gelombang dengan menggunakan ADCP pada tanggal 4 Oktober 2019 - 7 Oktober 2019 pada Perairan Pelabuhan Branta, didapatkan tinggi gelombang yang cukup bervariasi berkisar 0,001 meter hingga 0,4 meter. Tinggi gelombang dengan 
rentang tersebut tergolong kecil karena dibawah 1 meter. Hal ini dikarenakan Perairan Pelabuhan Branta terletak pada Selat Madura yang tertutup. Sedangkan periode gelombang berkisar antara 4 detik - 6 detik. Berdasarkan Rahayu (2000) menyatakan gelombang dengan periode $0,2-9$ detik merupakan gelombang yang ditimbulkan oleh adanya pengaruh angin sehingga disebut dengan gelombang angin (wind waves).

Berdasarkan analisis ukuran butir pada sedimen dasar Perairan Pelabuhan Branta didapatkan presentasi kandungan ukuran butir sebagai berikut:

Tabel 2. Analisa Ukuran Butir Sedimen

\begin{tabular}{|c|c|c|c|c|c|c|}
\hline \multirow{2}{*}{ Stasiun } & \multirow{2}{*}{ Longitude } & \multirow{2}{*}{ Latitude } & \multicolumn{3}{|c|}{ Kandungan (\%) } & \multirow{2}{*}{ Jenis Sedimen } \\
\hline & & & Pasir & Lanau & Lempung & \\
\hline 1 & $113^{\circ} 27^{\prime} 10,7208^{\prime \prime} \mathrm{E}$ & $7^{\circ} 13^{\prime} 12,3276 " \mathrm{~S}$ & 13,40 & 85,67 & 0,94 & Lanau \\
\hline 2 & $113^{\circ} 27^{\prime} 7,6716^{\prime \prime} \mathrm{E}$ & $7^{\circ} 13 ' 21,252^{\prime \prime} \mathrm{S}$ & 96,92 & 2,50 & 0,58 & Pasir \\
\hline 3 & $113^{\circ} 27^{\prime} 4,4312^{\prime \prime} \mathrm{E}$ & $7^{\circ} 13 ' 28,342^{\prime \prime} \mathrm{S}$ & 96,40 & 2,61 & 0,99 & Pasir \\
\hline 4 & $113^{\circ} 27^{\prime} 28,5696^{\prime \prime E}$ & $7^{\circ} 13 ' 29,7732 " S$ & 94,40 & 5,60 & 1,32 & Pasir \\
\hline 5 & $113^{\circ} 26^{\prime} 51,7344^{\prime \prime} \mathrm{E}$ & $7^{\circ} 13 ' 24,7764 " S$ & 95,73 & 3,09 & 1,19 & Pasir \\
\hline 6 & $113^{\circ} 26^{\prime} 34,5264^{\prime \prime} \mathrm{E}$ & $7^{\circ} 13 ' 25,0464 " \mathrm{~S}$ & 96,62 & 2,57 & 0,81 & Pasir \\
\hline 7 & $113^{\circ} 26^{\prime} 16,1304^{\prime \prime E}$ & $7^{\circ} 13 ' 24,8664 " \mathrm{~S}$ & 93,18 & 6,81 & 0,01 & Pasir \\
\hline 8 & $113^{\circ} 26^{\prime} 10,932^{\prime \prime} \mathrm{E}$ & $7^{\circ} 13^{\prime} 43,5432^{\prime \prime S}$ & 86,90 & 9,70 & 3,41 & Pasir \\
\hline 9 & $113^{\circ} 26^{\prime} 34,0656^{\prime \prime} \mathrm{E}$ & $7^{\circ} 13^{\prime} 43,4208^{\prime \prime S}$ & 19,10 & 78,49 & 2,41 & Lanau \\
\hline 10 & $113^{\circ} 26^{\prime} 52,1988^{\prime \prime} \mathrm{E}$ & $7^{\circ} 13^{\prime} 46,6608^{\prime \prime S}$ & 78,09 & 20,16 & 1,75 & Pasir \\
\hline 11 & $113^{\circ} 27^{\prime} 17,0028^{\prime \prime} \mathrm{E}$ & $7^{\circ} 13^{\prime} 46,5276 " \mathrm{~S}$ & 82,41 & 14,69 & 2,90 & Pasir \\
\hline 12 & $113^{\circ} 27^{\prime} 38,0412^{\prime \prime} \mathrm{E}$ & $7^{\circ} 13^{\prime} 43,4568^{\prime \prime} \mathrm{S}$ & 63,14 & 34,56 & 2,29 & Pasir Lanauan \\
\hline 13 & $113^{\circ} 27^{\prime} 38,2932^{\prime \prime E}$ & $7^{\circ} 14 ' 5,8956^{\prime \prime} \mathrm{S}$ & 17,26 & 82,72 & 0,02 & Lanau \\
\hline 14 & $113^{\circ} 27^{\prime} 13,482^{\prime \prime} \mathrm{E}$ & $7^{\circ} 14 ' 5,4744^{\prime \prime} S$ & 15,75 & 84,16 & 0,09 & Lanau \\
\hline 15 & $113^{\circ} 26^{\prime} 48,6996^{\prime \prime} \mathrm{E}$ & $7^{\circ} 14^{\prime} 9,2256^{\prime \prime} \mathrm{S}$ & 14,34 & 84,88 & 0,78 & Lanau \\
\hline 16 & $113^{\circ} 26^{\prime} 21,6348^{\prime \prime} \mathrm{E}$ & $7^{\circ} 14 ' 4,362^{\prime \prime} \quad S$ & 16,41 & 83,07 & 0,52 & Lanau \\
\hline 17 & $113^{\circ} 26 ' 28,7628^{\prime \prime} \mathrm{E}$ & $7^{\circ} 14 ' 33,8244 " \mathrm{~S}$ & 7,45 & 92,49 & 0,06 & Lanau \\
\hline 18 & $113^{\circ} 27^{\prime} 7,182^{\prime \prime} \quad \mathrm{E}$ & $7^{\circ} 14 ' 25,8252 " S$ & 10,39 & 89,03 & 0,58 & Lanau \\
\hline 19 & $113^{\circ} 27^{\prime} 21,2112^{\prime \prime} \mathrm{E}$ & $7^{\circ} 14^{\prime} 42,7272 " S$ & 8,01 & 91,97 & 0,02 & Lanau \\
\hline
\end{tabular}

Persentase ukuran butir sedimen tersebut kemudian diolah dengan ArcGIS 10.3 untuk mengetahui persebaran jenis sedimen pada Perairan Pelabuhan Branta, Pamekasan. Pengambilan sampel sedimen dilakukan pada berbagai kedalaman. Kedalaman perairan yang telah terkoreksi dengan pasang surut menunjukkan bahwa Perairan Pelabuhan Branta memiliki kedalaman yang akan semakin dalam ketika menjauhi pantai hingga kedalaman 29 meter seperti disajikan pada gambar 6.

Validasi pada penelitian ini menggunakan metode Root Mean Square (RMS). Metode ini digunakan untuk mengetahui akurasi hasil prakiraan model yang dibuat dengan data yang sebenarnya. Berdasarkan perhitungan metode RMS didapatkan nilai verifikasi kecepatan arus yaitu 0,1 . Menurut Minarrohman dan Pratomo (2017), jika hasil verifikasi arus menunjukan RMS $<1$ dan mendekati 0 maka hasil pemodelan arus yang dijalankan adalah baik dan valid. Sehingga data hasil pemodelan dapat dianalisa lebih lanjut. Validasi pada data gelombang didapatkan nilai RMSE sebesar 0,13 . Nilai tersebut berada dalam rentang $0,00-0,29$, yang menunjukkan tingkat kesalahan tergolong kecil. Hal ini mengacu 
pada Khofifah (2012) yang menyatakan bahwa rentang nilai RMSE 0,00 - 0,29 tergolong kedalam tingkat kesalahan kecil.
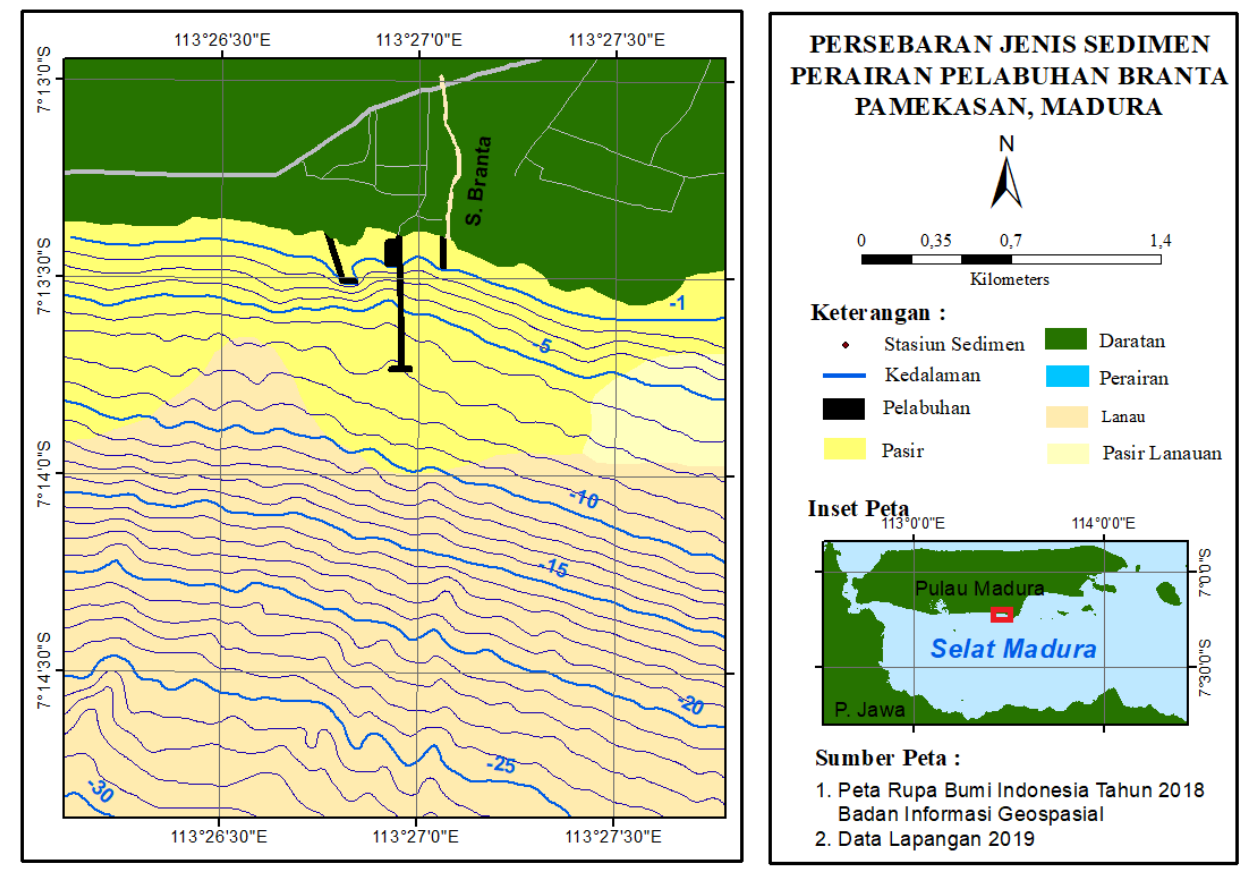

\section{Gambar 6. Peta Persebaran Jenis Sedimen}

Pemodelan pola arus disajikan dalam kondisi arus pada saat pasang tertinggi, saat pasang menuju surut, saat surut terendah dan saat surut menuju pasang yang disajikan pada gambar 7 . Hasil pemodelan arus pada saat pasang tertinggi dan saat surut menuju pasang menunjukkan vektor arus dominan menuju ke arah timur dan barat dengan mendekati daerah daratan. Kecepatan arus maksimum pada saat pasang tertinggi dan saat surut menuju pasang berturut-turut yaitu $0,1366 \mathrm{~m} / \mathrm{s}$ dan $0,2645 \mathrm{~m} / \mathrm{s}$. Sedangkan saat kondisi surut terendah dan saat pasang menuju surut, vektor arus dominan menuju tenggara yang berarti menunjukkan arus menuju ke arah laut. Kecepatan arus maksimum pada saat surut terendah dan pasang menuju surut secara berturut-turut yaitu $0,1977 \mathrm{~m} / \mathrm{s}$ dan $0,4087 \mathrm{~m} / \mathrm{s}$.

Bangunan pantai yang terdapat pada Pelabuhan Branta terdiri dari 3 bangunan. Bangunan tersebut yaitu jetty pada muara sungai, bangunan pelindung kolam pelabuhan dan dermaga yang menyerupai berbentuk T. Setengah bagian dari dermaga tersebut yang menjorok ke laut dibangun dengan menggunakan tiang pancang. Hal ini mengakibatkan arus dapat melalui celah dari tiang pancang tersebut, sehingga tidak banyak mempengaruhi pergerakan arus.

Hasil pemodelan gelombang yang didapatkan berupa tinggi gelombang dan arah datang gelombang. Arah penjalaran gelombang pada hasil pemodelan menunjukkan adanya pembelokan dengan perubahan arah yang sangat kecil, dengan arah datang gelombang pada laut sebesar $181^{\circ}-183^{\circ}$ menjadi $170^{\circ}-177^{\circ}$ pada daerah dekat pantai. Perubahan arah penjalaran ini terjadi akibat adanya variasi kedalaman selama penjalaran gelombang menuju pantai. Variasi kedalaman pada Perairan Pelabuhan Branta, selain mempengaruhi arah penjalaran gelombang juga mempengaruhi tinggi gelombang. Tinggi gelombang pada hasil pemodelan mengalami penurunan, pada daerah laut tinggi gelombang mencapai $0,0602 \mathrm{~m}-0,0700 \mathrm{~m}$, pada daerah dekat pantai tinggi gelombang menjadi $0,0291-0,0602 \mathrm{~m}$. Tinggi gelombang $0,00-0,02$ terjadi pada daerah pantai dan pada muara sungai. Adanya bangunan pantai juga mempengaruhi tinggi gelombang yang terjadi, dimana tinggi gelombang tepat sebelum terkena bangunan pantai sebesar 0,0485, setelah terkena bangunan pantai menjadi $0,0291 \mathrm{~m}-0.032 \mathrm{~m}$. 

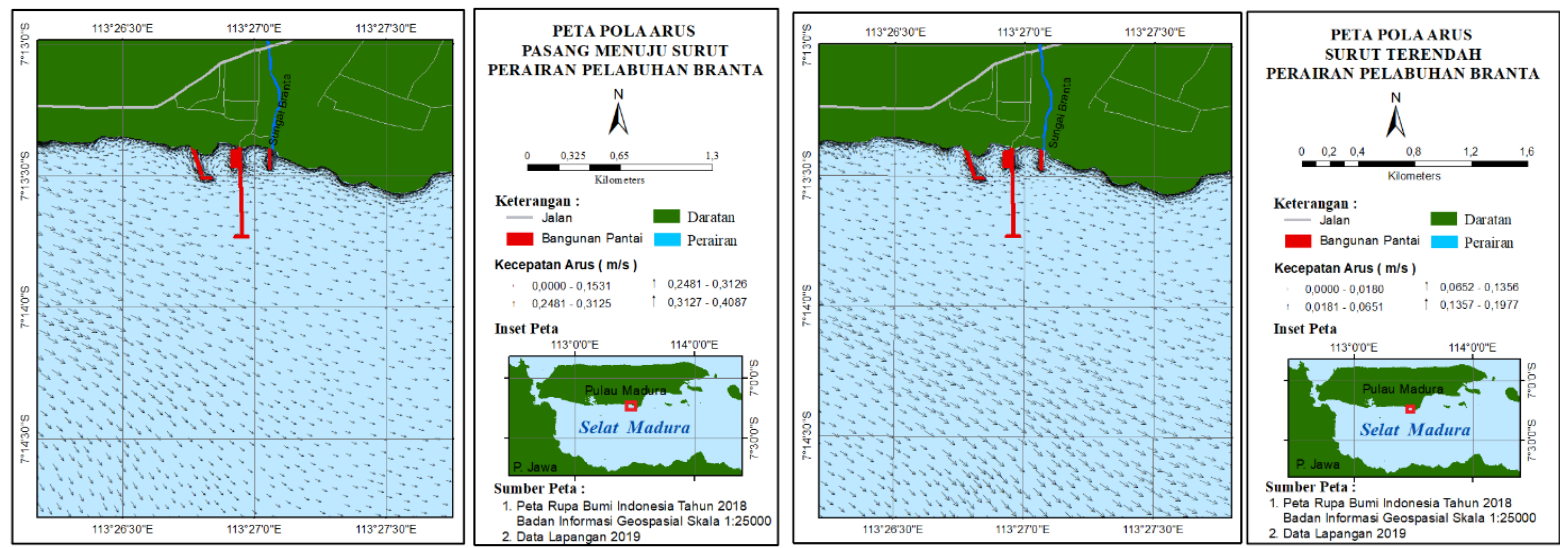

(a)

(b)

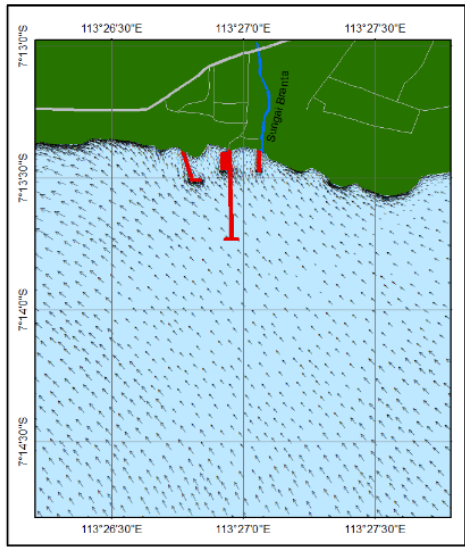

(b)

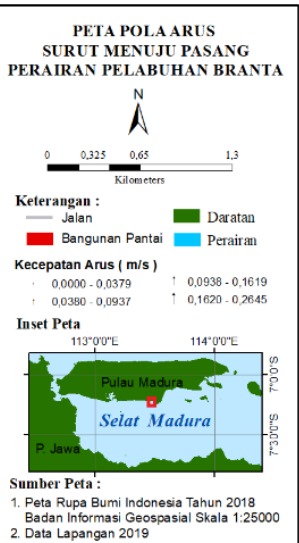

Badan Intormasi Geospessial Skala $1: 25000$
Bent

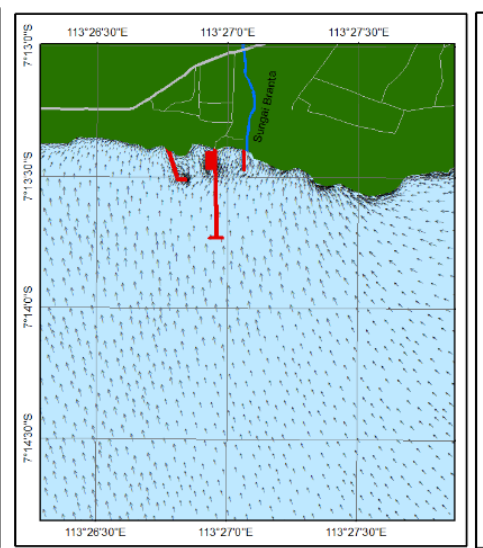

PETA POLAARUS PASANG TERTINGGI
RAIRAN PELABUHAN BRANTA $\AA^{N}$

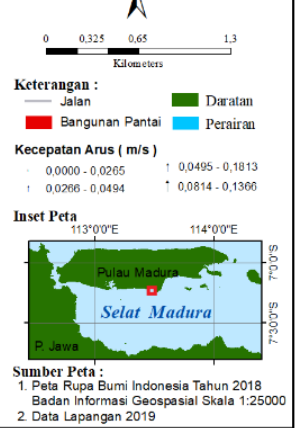

(d)

Gambar 7. Pola Arus (a) pasang menuju surut; (b) surut terendah;

(c) surut menuju pasang; (d) pasang tertinggi

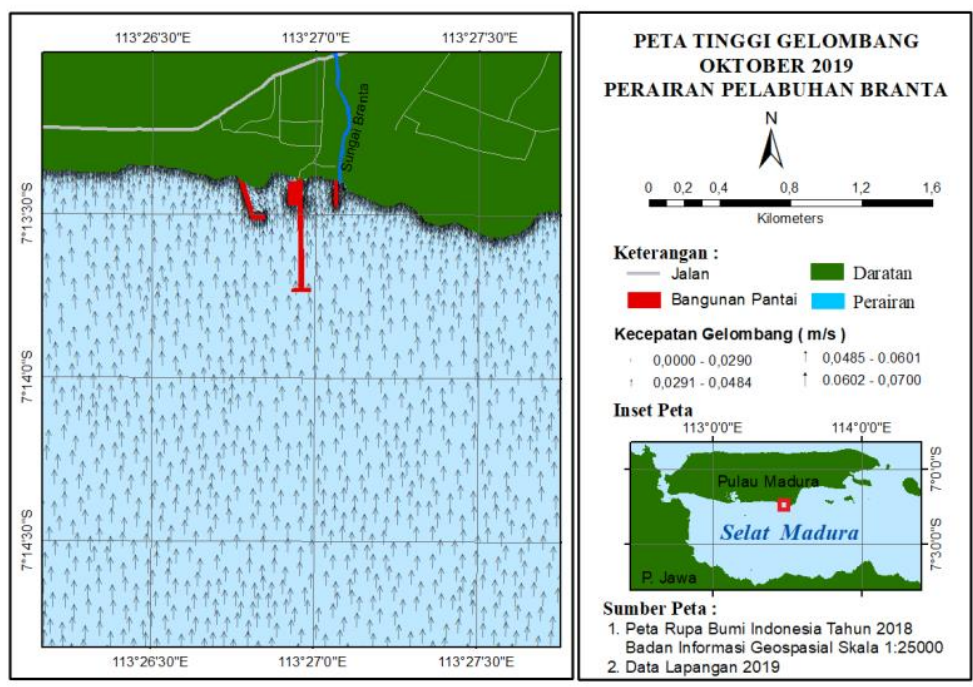

Gambar 8. Peta Tinggi Gelombang 
Pemodelan sedimen dasar dilakukan menggunakan MIKE21 dengan modul Sand Transport sehingga didapatkan perubahan dasar perairan (bed level change) pada area penelitian. Berdasarkan simulasi yang telah dilakukan dalam kurun waktu 1 hari, hasil pemodelan menunjukkan terdapat gradien warna. Hal ini menunjukkan terjadinya proses sedimentasi maupun erosi selama simulasi 1 hari. Pada perairan dengan jarak kurang dari $20 \mathrm{~m}$ dari garis pantai terjadi sedimentasi dengan nilai sebesar 0,00152 - 0,00412 m. Namun, pada daerah muara sungai tidak terjadi sedimentasi maupun erosi. Pada simulasi dalam 7 hari, terjadi proses sedimentasi maupun erosi yang semakin jelas terlihat. Pada perairan sejauh $20 \mathrm{~m}$ dari garis pantai terjadi sedimentasi sebesar 0,00152 - 0,012 $\mathrm{m}$ dan pada perairan dengan jarak lebih dari $200 \mathrm{~m}$ dari garis pantai terjadi erosi sebesar kurang dari 0,0087. Pada simulasi dalam 7 hari, daerah muara sungai belum menunjukkan terjadinya perubahan dasar perairan. Perubahan dasar tersebut mulai terlihat pada simulasi yang dilakukan dalam 31 hari. Muara sungai mengalami sedimentasi dengan nilai sebesar $0,0008 \mathrm{~m}-0,00152 \mathrm{~m}$, sedangkan pada perairan dengan jarak kurang dari $20 \mathrm{~m}$ dari garis pantai terjadi sedimentasi sebesar $0,02 \mathrm{~m}$, perairan dengan jarak $20 \mathrm{~m}-200 \mathrm{~m}$ dari garis pantai terjadi sedimentasi $0,0008-0,02 \mathrm{~m}$. Simulasi dalam 31 hari menunjukkan pada perairan dengan jarak lebih dari $200 \mathrm{~m}$ dari garis pantai terjadi erosi sebesar $0,0087-0,00238 \mathrm{~m}$.
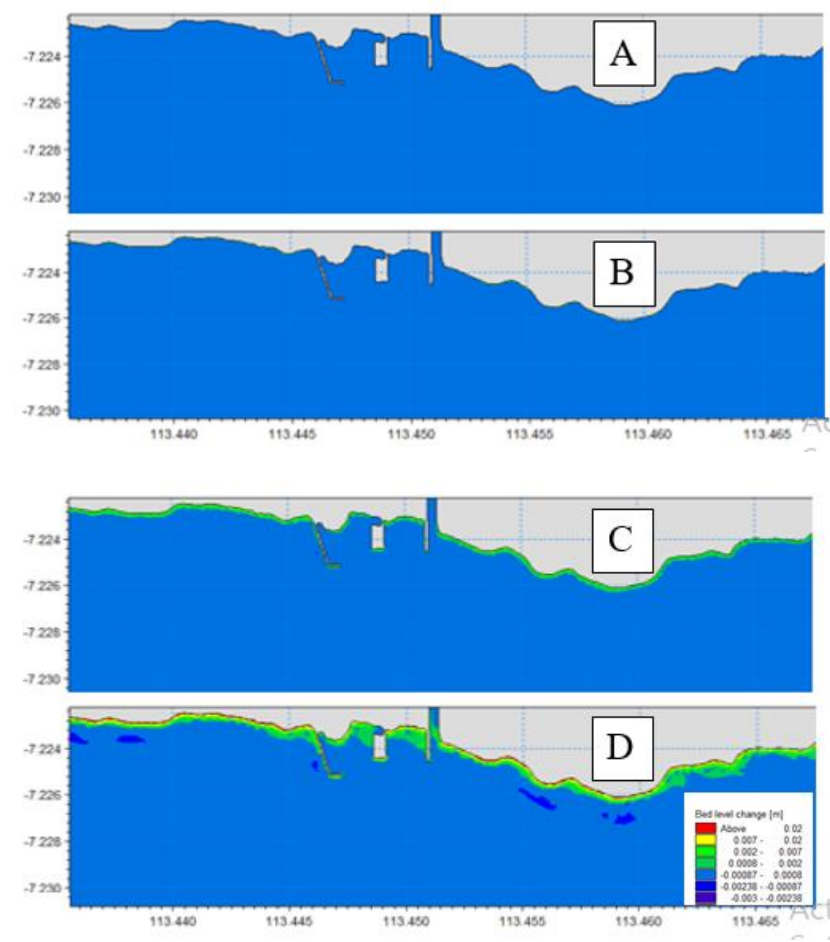

Gambar 9. Perubahan Dasar Perairan : (A) Awal Simulasi ; (B) 1 Hari ;

(C) 7 Hari ; (D) 31 hari

\section{Pembahasan}

Berdasarkan current rose yang ditunjukkan pada gambar dapat menggambarkan pergerakan arus dan arahnya. Hasil dari current rose menunjukan arus di perairan pelabuhan branta dominan bergerak ke arah barat laut dan tenggara. Arah arus yang bolak balik ini menandakan bahwa pola pergerakan arus dipengaruhi oleh fenomena pasang surut. Pola Arus di Perairan Pelabuhan Branta dominan arus pasut karena pola pergerakannya sesuai dengan pola pasang surut. Hal ini diperkuat oleh pernyataaan Hadi dan Radjawane (2009) bahwa pola arus yang bergerak secara bolak-balik, maka arus di perairan tersebut didominasi arus pasut. 
Hasil pemodelan arus dengan menggunakan MIKE21 diperoleh pola pergerakan arus laut mengikuti pola pasang surut pada lokasi penelitian. Hasil pemodelan ditampilkan dalam 4 kondisi yaitu pasang, pasang menuju surut, surut, dan surut menuju pasang. Hasil pemodelan menunjukkan pada kondisi pasang dan surut menuju pasang, air laut bergerak mendekati daratan. Kondisi berbeda terjadi pada saat surut dan pasang menuju surut, air laut bergerak menjauhi daratan menuju ke laut. Hal ini dikarenakan pada saat pasang dan surut menuju pasang, kondisi muka air akan naik maka air laut akan mendekati daratan sehingga pola arus menunjukkan air laut bergerak dari laut menuju daratan. Sedangkan pada kondisi surut dan pasang menuju surut, muka air laut akan turun maka air laut akan bergerak menjauhi daratan sehingga pola arus menunjukkan air laut bergerak dari daratan menuju laut.

Kecepatan arus hasil pemodelan menunjukkan kecepatan arus pada kondisi surut dan pasang lebih rendah daripada kondisi pasang menuju surut dan surut menuju pasang. Hal ini dikarenakan pada kondisi pasang dan surut maka arus cenderung diam dan akan bergerak ketika terdapat perubahan elevasi muka air, sehingga kecepatan arus yang lebih tinggi akan terjadi pada saat kondisi menuju pasang maupun menuju surut. Kondisi ini sesuai dengan pernyataan Brown et al., (1989) bahwa pada saat surut terendah dan pasang tertinggi maka terjadi kecepatan arus pasut minimum, sedangkan pada saat transisi surut menuju pasang dan pasang menuju surut terjadi kecepatan maksimum. Hal ini mengakibatkan perubahan kecepatan dan arah arus pasut.

Berdasarkan hasil pengukuran gelombang dilapangan, didapatkan tinggi gelombang dan periode gelombang. Tinggi gelombang yang didapatkan sebesar $0,001 \mathrm{~m}$ hingga $0,4 \mathrm{~m}$ dengan periode gelombang sebesar 4 detik -6 detik. Berdasarkan periode gelombang tersebut, gelombang yang terjadi pada perairan Pelabuhan Branta merupakan gelombang yang dibangkitkan oleh angin. Hal ini mengacu pada Rahayu (2000), periode gelombang dalam rentang 0,2 detik - 9 detik termasuk gelombang angin. Angin sebagai pembangkit gelombang mempengaruhi tinggi gelombang yang terjadi pada perairan pelabuhan branta.

Gelombang yang dibangkitkan oleh angin, maka arah dan tinggi gelombang yang dihasilkan akan sangat bergantung dengan angin yang menimbulkannya. Analisis statistik angin berupa windrose pada gambar 5 menunjukkan angin pada bulan oktober di perairan pelabuhan branta, dominan berhembus dari arah selatan sebesar $183^{\circ}$. Sehingga diperoleh arah penjalaran gelombang dari arah $183^{\circ}$ menuju ke daratan.

Arah penjalaran gelombang mengalami pembelokan (refraksi) ketika mendekat ke daratan dikarenakan adanya variasi kedalaman selama penjalaran gelombang menuju pantai. Perbedaan kontur kedalaman menyebabkan gelombang yang melaju mendekati pantai cenderung dibelokkan sehingga muka gelombang akan sejajar dengan garis pantai dan tinggi gelombang akan semakin kecil. Adanya bangunan pantai mengakibatkan gelombang yang datang dari laut akan menabrak bangunan pantai tersebut, kemudian masuk kedalam daerah yang terlindungi dan mengakibatkan tinggi gelombang menjadi lebih kecil. Hal ini sesuai dengan Triatmodjo (1999) yang menyatakan gelombang yang menjalar dari laut dalam menuju laut dangkal akan mengalami refraksi dimana gelombang akan mengalami penurunan ketinggian yang disebabkan oleh adanya perbedaan kontur kedalaman.

Hasil pengukuran gelombang dan peramalan gelombang menunjukkan tinggi gelombang termasuk kecil karena berada di bawah $1 \mathrm{~m}$. Hal tersebut dikarenakan angin yang sebagai pembangkit gelombang juga memiliki kecepatan kecil $(0 \mathrm{~m} / \mathrm{s}-6 \mathrm{~m} / \mathrm{s})$. Kecepatan angin yang kecil ini diakibatkan terjadi pada musim peralihan, sesuai dengan Bayong (2004) dan Wyrtki (1961) dalam Sugianto (2010) yang menyatakan bahwa kecepatan angin akan lebih lemah pada musim peralihan dibandingkan musim barat dan musim timur karena adanya pola sirkulasi atmosfer dimana pada musim peralihan menyebabkan matahari bergerak melintasi khatulistiwa sehingga kecepatan angin menjadi lemah.

Berdasarkan dari hasil analisa sedimen, didapatkan bahwa ukuran butir sedimen pada perairan pelabuhan branta yaitu pasir, pasir lanauan dan lanau. Sebaran ukuran butir sedimen pada lokasi penelitian ditunjukkan pada gambar 8. Sedimen dengan ukuran butir berupa pasir terdapat pada daerah dekat pantai dan muara sungai, pada wilayah sungai didapatkan ukuran butir sedimen berupa lanau, sedangkan pada daerah laut didapatkan ukuran butir berupa pasir lanauan dan lanau. Hasil analisa sedimen menunjukkan semakin menuju perairan laut lepas, sedimen yang tersebar akan semakin halus. 
Sedimen berupa pasir ditemukan pada muara sungai dan sepanjang pantai. Kecepatan arus yang kuat pada sungai membawa material sedimen berupa pasir dan lanau menuju laut. Arus yang berasal dari sungai semakin mengecil pada saat di muara sungai karena bertemu dengan arus dari arah laut, hal ini menyebabkan sedimen berupa pasir akan terendapkan pada daerah muara sungai dan pantai di sekitarnya. Gelombang yang kecil tidak mampu membawa sedimen dengan ukuran butir besar (pasir) dalam jarak yang jauh, sehingga hanya menyebar pada daerah sepanjang pantai, sedangkan ukuran butir lebih halus akan terbawa arus menuju laut. Selain itu, pada perairan sekitar pantai bagian timur terdapat terumbu karang yang dapat menyebabkan sedimen berupa pasir akan terendapkan, sedangkan sedimen yang lebih halus mampu melewatinya dan terendapkan di laut yang lebih dalam.

Ukuran butir dominan lanau ditemukan pada daerah lepas pantai, hal ini dikarenakan lanau dengan ukuran butir yang kecil mudah untuk terbawa oleh arus ke arah laut sehingga terendapkan pada perairan yang dalam. Ukuran butir halus berupa lempung pada lokasi penelitian didapatkan persentase terbesar yaitu $3,41 \%$. Persentasi yang rendah pada kandungan lempung tersebut dikarenakan aktifitas kapal yang ramai pada Perairan Pelabuhan Branta sehingga menyebabkan kondisi oseanografi tidak mendukung ukuran butir lempung untuk mengendap.

Berdasarkan hasil pemodelan perubahan dasar perairan didapatkan bahwa terjadi sedimentasi pada daerah dekat pantai yang semakin bertambah seiring dengan semakin lama waktu simulasi. Pada hari 1 simulasi, perubahan pada daerah pantai dengan cakupan wilayah yang kecil. Pada simulasi hari ke 7, hasil pemodelan menunjukkan terjadi sedimentasi yang lebih besar dari pada hari 1 dengan nilai yang lebih tinggi. Cakupan sedimentasi yang lebih besar ditunjukkan pada simulasi hari ke 31, yang terjadi pada daerah pantai dan juga muara sungai.

Faktor yang mempengaruhi pengangkutan sedimen dasar diantaranya yaitu gelombang dan arus. Hasil peramalan gelombang pada bulan Oktober 2019 berada dalam rentang $0.001-0.8 \mathrm{~m}$. Tinggi gelombang tersebut relatif kecil karena tinggi gelombang di bawah 1 meter sehing ga tidak berpengaruh banyak pada sebaran sedimen. Gelombang dengan ketinggian yang relatif kecil tidak memungkinkan memindahkan sedimen dalam rentang jarak yang panjang. Hal ini ditandai dengan perubahan dasar perairan dalam waktu 31 hari, sedimentasi yang terjadi hanya terdapat pada daerah dekat pantai.

Arus yang terjadi pada Perairan Pelabuhan Branta memiliki kecepatan yang lebih besar pada daerah laut daripada pada daerah pantai. Semakin besar kecepatan arus pada daerah laut menyebabkan terjadinya erosi pada daerah laut, dan akan terbawa ke arah perairan dekat darat, sehingga terjadi sedimentasi pada daerah dekat pantai. Sedimentasi yang dominan terjadi pada daerah pantai juga diakibatkan karena kecepatan arus yang kecil pada wilayah perairan tersebut. Semakin dekat dengan pantai, kecepatan arus akan semakin berkurang, hal ini mengakibatkan arus tidak mampu untuk membawa material sedimen dari pantai, sehingga terjadi sedimentasi sepanjang pantai.

\section{KESIMPULAN}

Berdasarkan penelitian pada Perairan Pelabuhan Branta, Pamekasan dapat disimpulkan memiliki tiga jenis ukuran butir sedimen yaitu pasir, lanau pasiran dan lanau. Perubahan dasar perairan yang terjadi pada Perairan Pelabuhan Branta selama bulan Oktober 2019 berdasarkan hasil pemodelan menunjukkan terjadi sedimentasi dengan ketebalan sebesar $0,02 \mathrm{~m}$ pada lokasi antara garis pantai hingga jarak $20 \mathrm{~m}$, sedimentasi sebesar $0,0008 \mathrm{~m}-0,02 \mathrm{~m}$ pada perairan dengan dengan jarak $20 \mathrm{~m}$ hingga $200 \mathrm{~m}$ dari garis pantai, sedangkan pada perairan dengan jarak lebih dari $200 \mathrm{~m}$ dari pantai terjadi erosi sebesar kurang dari $0,00238 \mathrm{~m}$.

\section{DAFTAR PUSTAKA}

Abdurrahman, A. Latief, R.U. 2017. Kajian Pengembangan Penyelenggaraan Pelabuhan Branta, Kabupaten Pamekasan, Jawa Timur. Universitas Hasanuddin

Astuti, EH. Ismanto, A. Saputro, S. 2016. Studi Pengaruh Gelombang Terhadap Transport Sedimen di Perairan Timbulsloko Kabupaten Demak Jawa Tengah. Jurnal Oseanografi, Vol 5 (1) : 77-85

Brown, E., A. Colling., D. Park., J. Phillips., D. Rothery., J. Wright. 2001. Ocean Circulation Second Edition. Milton Keynes: Open University. 
Diposaptono, S. 2011. Sebuah Kumpulan PemikiranMitigasi Bencana dan Adaptasi Perubahan Iklim, Direktorat Pesisir dan Lautan-Kementerian Kelautan dan Perikanan, Jakarta.

Fahmi, MB. 2015. Analisa Laju Sedimentasi Akibat Rencana Reklamasi Di Teluk Segendis Bontang. Institut Teknologi Sepuluh Nopember : Skripsi

Hadi, S. Ivonne M. Radjawane. 2009. ArusLaut. Institut Teknologi Bandung, Bandung.

Ismanto, A. Zainuri, M. Hutabarat, S. Sugianto, DN. Widada, S. Wirasatriya, A. 2017. Sediment Transport Model In Sayung Distric, Demak. International Conference on Tropical and Coastal Region Eco Development

Minarrohman, MG. Pratomo, DG. 2017. Simulasi Arus dan Distribusi Sedimen secara 3 Dimensi di Pantai Selatan Jawa. Jurnal Teknik ITS Vol 6 (2) : G174-G179

Satriadi, A. 2013. Kajian Transpor Sedimen Tersuspensi Untuk Perencanaan Pembangunan Pelabuhan Bojonegara Banten.

Siswanto, A. D. 2007. Studi Aspek Geologi di Perairan Delta Bodri, Kabupaten Kendal. Embryo, 4(2): 114-123.

Sugianto, DN. 2010. Model Distribusi Data Kecepatan Angin dan Pemanfaaatannya dalam Peramalan Gelombang di Perairan Laut Paciran, Jawa Timur. Jurnal Ilmu Kelautan, Vol 15 (3) : 143-152

Witantono, AD. Khomsin. 2015. Pemodelan Aliran Sedimen Di Kolam Pelabuhan (Studi Kasus : Kolam 1 Pelabuhan Tanjungpriok, Jakarta). Jurnal Geoid Vol 1(1): 22 - 28

Triatmodjo, B. 1999. Teknik Pantai.Yogyakarta : Beta Offset 